\title{
Diabetic threesome (hyperglycaemia, renal function and nutrition) and advanced glycation end products: evidence for the multiple-hit agent?
}

\author{
Kateřina Kaňková \\ Department of Pathophysiology, Faculty of Medicine, Masaryk University, Komenského nám 2, 66243 Brno, \\ Czech Republic
}

\begin{abstract}
Complex chemical processes termed non-enzymic glycation that operate in vivo and similar chemical interactions between sugars and proteins that occur during thermal processing of food (known as the Maillard reaction) are one of the interesting examples of a potentially-harmful interaction between nutrition and disease. Non-enzymic glycation comprises a series of reactions between sugars, $\alpha$-oxoaldehydes and other sugar derivatives and amino groups of amino acids, peptides and proteins leading to the formation of heterogeneous moieties collectively termed advanced glycation end products (AGE). AGE possess a wide range of chemical and biological properties and play a role in diabetes-related pathology as well as in several other diseases. Diabetes is, nevertheless, of particular interest for several reasons: (1) chronic hyperglycaemia provides the substrates for extracellular glycation as well as intracellular glycation; (2) hyperglycaemia-induced oxidative stress accelerates AGE formation in the process of glycoxidation; (3) AGE-modified proteins are subject to rapid intracellular proteolytic degradation releasing free AGE adducts into the circulation where they can bind to several pro-inflammatory receptors, especially receptor of AGE; (4) kidneys, which are principally involved in the excretion of free AGE adducts, might be damaged by diabetic nephropathy, which further enhances AGE toxicity because of diminished AGE clearance. Increased dietary intake of AGE in highly-processed foods may represent an additional exogenous metabolic burden in addition to AGE already present endogenously in subjects with diabetes. Finally, inter-individual genetic and functional variability in genes encoding enzymes and receptors involved in either the formation or the degradation of AGE could have important pathogenic, nutrigenomic and nutrigenetic consequences.
\end{abstract}

Advanced glycation end products: Diabetes mellitus: Diabetic nephropathy: Nutrigenetics

Diabetes mellitus is the most common metabolic disease. Its prevalence is steadily rising (with few exceptions) globally, having already reached epidemic proportions in industrialised countries. Current WHO estimates predict that the number of individuals with diabetes will reach approximately 300 million by $2025^{(1)}$. The diabetes mellitus epidemic is paralleled by body-weight changes (overweight or obesity), and in both cases there is a clear-cut correlation; the faster the socio-economic progress (and subsequent lifestyle changes) in a given society the steeper the rise in the incidence and prevalence of diabetes mellitus and obesity. Both common types of diabetes mellitus, type 1 (T1DM) and type 2 (T2DM), are ethiopathogenetically 'complex' diseases with a certain extent of genetic predisposition and a substantial influence of environmental factors (particularly diet and physical (in)activity), although the phenotypic complexity and prevalence of T2DM is much higher. Since diabetes mellitus is characterised by profound abnormalities in energysubstrate partitioning as a result of deficient insulin action (either absolute or relative), nutrition plays a particularly important role in disease progression and its long-term outcomes.

Energy-substrate overload in diabetes (i.e. hyperglycaemia and high NEFA) leads to multiple alterations of intermediate metabolism, presumably as a result of hyperglycaemia- and NEFA-driven overproduction of reactive oxygen species (ROS) in the mitochondrial

Abbreviations: AGE, advanced glycation end products; CML, $\mathrm{N}_{\varepsilon}$-carboxymethyl-lysine; CRP, C-reactive protein, FN3K, fructosamine-3-kinase; GAPDH, glyceraldehyde 3-phosphate dehydrogenase; RAGE, receptor for AGE; ROS, reactive oxygen species; T1DM, type 1 diabetes mellitus; T2DM, type 2 diabetes mellitus.

Corresponding author: Dr Kateřina Kaňková, fax +420 549494 340, email kankov@med.muni.cz 
respiratory chain (since both glucose and NEFA provide the same electron donors NADH and $\left.\mathrm{FADH}_{2}\right)^{(2,3)}$. One of these alterations leads to the formation of heterogeneous moieties, collectively termed advanced glycation end products (AGE), by the processes of non-enzymic glycation and glycoxidation, which comprise a series of reactions between reducing sugars, $\alpha$-oxoaldehydes and other sugar derivatives and amino groups of amino acids, peptides and proteins. A mounting body of evidence suggests that AGE possess a wide range of chemical and biological effects and play a role in diabetes-related pathology as well as in several other diseases ${ }^{(4-7)}$. Similar chemical interactions between sugars and proteins occur during thermal processing of food and have been known to the food chemists for approximately 100 years as a result of the pioneering studies of Louis Camille Maillard ${ }^{(8)}$. This chemical interaction is termed the Maillard reaction and the compounds formed are Maillard reaction products; chemically they are largely similar to the AGE formed in vivo. Diet is believed to be a potentially important source of exogenous AGE; however, assessment of the true impact of dietary AGE has recently been the subject of intensive research.

The current and in particular the future extent of the diabetes mellitus epidemic makes it crucial to understand its ethiopathogenesis (including the role of AGE) from the whole body to the molecular level. The following review summarises: (A) the contribution of the principal pathogenic features of diabetes (chronic hyperglycaemia) to the enhanced formation of endogenous AGE, and the biological effects of AGE; therefore establishing the 'first' hit of the multiple-hit hypothesis being put forward in the present paper for the role of AGE in diabetes; (B) the current knowledge of the metabolic fate of AGE, the renal excretion of AGE and its impairment by diabetic nephropathy (as well as other causes), which might thus constitute the 'second' hit in increasing the AGE burden; (C) the most controversial topic, and potentially the 'third' hit, i.e. whether increased dietary intake of AGE in highlyprocessed foods consumed by patients with diabetes might represent an important source of AGE for the organism in question and, therefore, pose the additional metabolic burden (the 'third' hit); (D) in addition, based on data available, the possibility that an individual's genetic makeup may influence the formation and processing of AGE (i.e. nutrigenetics) and that AGE, conversely, may influence the integrity and expression of the genome (i.e. nutrigenomics).

\section{The 'first' hit: increased formation of endogenous advanced glycation end products}

\section{Metabolic derangements in diabetes and mechanisms of cell damage by hyperglycaemia}

Absolute (T1DM) or relative (T2DM) insulin deficiency results in impaired postprandial glucose uptake by skeletal muscle, decreased glucose processing into glycogen, inadequate suppression of hepatic gluconeogenesis and lipolysis in adipose tissue (NEFA further interferes with glucose oxidation via the glucose-NEFA cycle). If the cell cannot efficiently down regulate insulin-independent glucose intake in hyperglycaemia it becomes overloaded, which has been convincingly shown for endothelial ${ }^{(9,10)}$, mesangial $^{(11)}$ and renal tubular ${ }^{(12)}$ cells, all of which are targets for vascular damage by hyperglycaemia in diabetes. In the case of endothelial cells the expression of some types of facilitative glucose transporters stay stable or are moderately down regulated by glucose (GLUT1), while others (GLUT2) are up regulated ${ }^{(9,10)}$. Intracellularly, glucose is metabolised via glycolysis and the Krebs cycle, and the electron donors (NADH and $\mathrm{FADH}_{2}$ ) generated then supply electrons for the electron transport chain in the mitochondria to be used to generate $\mathrm{H}^{+}$membrane potential for the production of ATP via ATP synthase. Increased availability of glucose and glycolytic intermediates have been shown to provide substrates for several pathways that are believed to be largely responsible for the cell damage induced by hyperglycaemia ${ }^{(2)}$ : polyol and hexosamine pathways; dicarbonyl production (mainly methylglyoxal by degradation of triosephosphates) and non-enzymic glycation (AGE); de novo synthesis of diacylglycerol with subsequent activation of protein kinase $\mathrm{C}$ isoforms. The overall effects of these abnormalities are changes in gene expression by activation of certain transcription factors (mainly NF- $\kappa \mathrm{B}$ ), post-translational modification of intra- and extracellular proteins (glycation), alteration of cellular signalling (by activation of kinases), endoplasmic reticulum stress leading to unfolded protein response, impairment of antioxidant capacity etc. (for details, see Brownlee $\left.{ }^{(2,13)}\right)$.

Recently, a 'unifying' hypothesis was proposed that strengthens the role of mitochondrial ROS overproduction and subsequent DNA oxidative damage as a potent accelerator of these abnormalities (originally seen merely as a result of increased substrate availability because of allosteric inhibition and thus accumulation of glycolytic intermediates). Hyperglycaemia overloads the mitochondrial electron transport chain by increased availability of reducing equivalents (mainly on complex III) and a larger proportion of $\mathrm{O}_{2}$ is then partly reduced with single electrons to superoxide ${ }^{(13)}$. Overexpression of manganese superoxide dismutase or uncoupling protein-1 abolishes hyperglycaemia-induced ROS generation in vitro ${ }^{(14)}$. In fact, NADH:NAD ${ }^{+}$rather than the absolute amount of $\mathrm{NADH}$ seems to be important for the intensity of mitochondrial superoxide generation ${ }^{(15)}$, and since hyperglycaemia-induced ROS generation directly contributes to an increase in the NADH:NAD ${ }^{+}$(see later), diabetes represents a vicious circle in relation to oxidative stress. ROS can oxidatively damage most types of macromolecules; however, oxidative damage of DNA (strand breaks) is particularly important since it requires energyconsuming repair. Ribosylation of multiple proteins by poly-ADP-ribose polymerase, including auto-ribosylation of poly-ADP-ribose polymerase, itself initiates and facilitates DNA repair ${ }^{(16)}$. NAD ${ }^{+}$serves as a donor of ADP-ribose and its consumption by poly-ADP-ribose polymerase contributes to its decreased availability (an increase in $\mathrm{NADH}: \mathrm{NAD}^{+}$), further ROS generation and a decrease in ATP formation. Pharmacological inhibition of polyADP-ribose polymerase in vitro can suppress all these abnormalities in streptozotocin-induced diabetes ${ }^{(17)}$. 
Depletion of $\mathrm{NAD}^{+}$also inhibits the key glycolytic enzyme glyceraldehyde 3-phosphate dehydrogenase (GAPDH) and causes the accumulation of upstream glycolytic intermediates and their processing in alternative metabolic pathways (see earlier discussion, p. 61). Experimentally, GAPDH antisense oligonucleotides applied to cells cultured in $5 \mathrm{~mm}$-glucose completely mimics hyperglycaemia by activating pathways leading to vascular damage to the same extent as in $30 \mathrm{~mm}$-glucose culture conditions $^{(18)}$. GAPDH is generally viewed as a classical glycolytic enzyme; however, it is now clear that it is a multifunctional protein with diverse functions in numerous cellular processes including apoptosis and DNA repair ${ }^{(19-21)}$. GAPDH translocates to the nucleus under a variety of stressors, most of which are associated with oxidative stress. Interestingly, poly-ADP-ribosylation of GAPDH itself seems to be one of the likely events enabling its nuclear translocation (further slowing down the rate of glycolysis) and yet another factor responsible for the harmful effect of hyperglycaemia ${ }^{(18)}$.

\section{Formation of advanced glycation end products in vivo by non-enzymic glycation}

Non-enzymic glycation (also termed the Maillard reaction in some contexts) of proteins involves interplay of serial and parallel reactions between protein residues (mainly lysine and arginine) and sugars, $\alpha$-oxoaldehydes (dicarbonyls) and other sugar derivatives (in vivo mainly triosephosphate derivatives) generating early (pre-AGE) and advanced glycation products (AGE) ${ }^{(22)}$. Glycation is one of the most common types of protein modification and spontaneous damage of proteins, which affects approximately $0 \cdot 1-0 \cdot 2 \%$ of the arginine and lysine residues in vivo ${ }^{(22)}$. Glycation of proteins proceeds with variable rate and extent during the lifespan of proteins in tissues and body fluids under physiological conditions, but it is more intensive in several disease conditions such as diabetes $^{(23)}$, atherosclerosis ${ }^{(24)}$, neurodegenerative diseases $^{(25)}$, osteoarthritis ${ }^{(26)}$ and renal failure ${ }^{(27)}$. The rate of reaction depends on variables such as temperature, $\mathrm{pH}$ and carbonyl:amine, and is thus topically and temporally variable. Generation of some AGE is substantially enhanced in the presence of ROS and some AGE are formed exclusively under oxidative conditions (hence the alternative term 'glycoxidation'). Originally, glycation was considered to be a type of post-translational modification that occurs mostly in long-lived proteins (e.g. collagen, crystalline); however, it is now clear that AGE are formed also in short-lived proteins, including the cellular proteome ${ }^{(4,22)}$.

Glycating agents in vivo include free sugars (glucose), glycolytic intermediates such as sugar phosphates (glucose- and fructose-6-phosphates) and dicarbonyls (methylglyoxal, glyoxal and 3-deoxyglucosone). Sugars are reactive towards lysine residues while dicarbonyls are mainly reactive towards arginine residues of proteins. Glycation by sugars proceeds through the early (Schiff's bases) and intermediate stages (Schiff's bases undergo the Amadori rearrangement to fructosamines) towards the formation of heterogeneous moieties collectively termed AGE. If the initial glycating agent is glucose the initial product is termed a fructosamine. Probably the best-studied fructosamine to date is $\mathrm{HbA}_{1 \mathrm{c}}$, which is glycated on the $\mathrm{NH}_{2}$-terminal valine of the $\beta$-globin chain, although $\mathrm{Hb}$ can also be glycated on several other lysine residues. Since its discovery in $1968^{(28)} \mathrm{HbA}_{1 \mathrm{c}}$ has been established as a widely used and very useful marker of medium- to long-term compensation of diabetes with a certain predictive value ${ }^{(29)}$. Quantitatively, however, fructoselysine is the most abundant early glycation product and fructosamine in vivo. Fructosamines are unstable products that slowly degrade to form AGE.

Fructosamines were traditionally considered to be a major source of AGE in vivo. Recently, however, as a result of advances in the methodology available for the precise chemical characterisation and quantification of pre-AGE and AGE (particularly liquid chromatography with tandem $\mathrm{MS}^{(30)}$ ), it has became apparent that dicarbonyl-derived AGE are the predominant class of AGE in vivo ${ }^{(22)}$. Dicarbonyls are formed from the triosephosphates glyceraldehyde 3-phosphate and dihydroxyacetone phosphate (methylglyoxal), lipid peroxidation (glyoxal), fragmentation of early glycation products by the Namiki pathway $^{(31)}$ (glyoxal, 3-deoxyglucosone), oxidative degradation of nucleotides (glyoxal) and ketone body metabolism (methylglyoxal) and by enzymic degradation of fructosamines $^{(32,33)}$ (3-deoxyglucosone). In diabetes the triosephosphates are the most important source of dicarbonyls as a result of the previously described inhibitory effects of hyperglycaemia on GAPDH function. GAPDH activity has been shown to be the most important determinant of methylglyoxal concentration for a given glucose level (with an inverse correlation between GAPDH activity and methylglyoxal level) ${ }^{(34)}$. The products of sugar oxidation, methylglyoxal, glyoxal and 3-deoxyglucosone, react with mainly arginine residues of proteins and form AGE directly. Dicarbonyl-derived AGE on arginine residues, the hydroimidazolones (methylglyoxal- $\mathrm{H}$, glyoxal-H, 3-deoxyglucosone-H), are the most abundant AGE in vivo in body fluids as well as in cellular protein (representing approximately $1 \%$ of the total arginine in some cell types) ${ }^{(22)}$. The concentration of dicarbonyls as well as dicarbonyl-derived hydroimidazolones has been shown to be significantly increased in patients with diabetes ( $\leq 3$-fold for glycated plasma proteins, and $\leq 10$-fold for glycation-free adducts; see p. 65) compared with controls without diabetes ${ }^{(35,36)}$. The level of dicarbonyls correlates with glycaemia, and variations in postprandial glucose contribute substantially to the rise of dicarbonyls (and thus dicarbonyl-derived AGE), while levels of $\mathrm{HbA}_{1 \mathrm{c}}$ do not reflect the postprandial glucose fluctuations ${ }^{(37)}$. Apart from the arginine-based dicarbonyl-derived AGE several other classes of AGE have been identified and chemically characterised (an overview of the current AGE classification based on their chemical structure and source is presented in Table 1).

\section{Enzymic defence against glycation}

Although the formation of pre-AGE and AGE is a non-enzymic process, e.g. methylglyoxal arises by nonenzymic phosphate elimination from the two intermediates 
Table 1. Current classification of advanced glycation end products (AGE)

\begin{tabular}{|c|c|c|c|}
\hline Class & Members & Source and target $A A$ & Relative quantity in vivo \\
\hline Hydroimidazolones (HY) & $\begin{array}{l}\text { G-HY } \\
\text { MG-HY } \\
\text { 3DG-HY }\end{array}$ & $\begin{array}{l}\text { G, Arg } \\
\text { MG, Arg } \\
\text { 3DG, Arg }\end{array}$ & $\begin{array}{l}\text { Absolutely highest in vivo } \\
\text { (approximately } 90 \% \text { of all } \\
\text { glycated plasma protein) } \\
\text { with MG-HY predominance }\end{array}$ \\
\hline Monolysyl adducts & $\begin{array}{l}\mathrm{N}_{\varepsilon} \text {-carboxymethyl-lysine } \\
\mathrm{N}_{\varepsilon} \text {-carboxyethyl-lysine } \\
\text { Pyrraline }\end{array}$ & $\begin{array}{l}\text { G, Lys } \\
\text { MG, Lys } \\
\text { 3DG, Lys }\end{array}$ & $\begin{array}{l}10 \times \text { lower than } \mathrm{HY} \\
\quad \text { (approximately } 10 \% \text { of } \\
\text { all glycated plasma protein) }\end{array}$ \\
\hline $\begin{array}{l}\text { Bis(lysyl) imidazolium } \\
\text { cross-links }\end{array}$ & $\begin{array}{l}\text { MG-derived lysine dimer (MOLD) } \\
\text { G-derived lysine dimer } \\
\text { 3DG-derived lysine dimer } \\
\text { Glucosepane }\end{array}$ & $\begin{array}{l}\text { MG, Lys } \\
\text { G, Lys } \\
\text { 3DG, Lys } \\
\text { FN, Lys }\end{array}$ & $\begin{array}{l}\text { Minimally }(<1 \% \text { of all } \\
\text { glycated plasma protein) } \\
\text { with MOLD predominance }\end{array}$ \\
\hline AGE fluorophores & $\begin{array}{l}\text { Pentosidine } \\
\text { Argpyrimidine }\end{array}$ & $\begin{array}{l}\text { 3DG, Lys or Arg } \\
\text { MG, Arg }\end{array}$ & $\begin{array}{l}100-1000 \times \text { lower than } \\
\text { HY (approximately } 1 \% \text { of all } \\
\text { glycated plasma protein) }\end{array}$ \\
\hline
\end{tabular}

3DG, 3-deoxyglucosone; FN, fructosamine; G, glyoxal; MG, methylglyoxal; AA, amino acid.

of glycolysis glyceraldehyde 3-phosphate and dihydroxyacetone phosphate (approximately $0 \cdot 2-1 \%$ of the flux of triosephosphates under normoglycaemic conditions ${ }^{(38)}$ ), organisms including man have developed several enzymic detoxification systems to deal with those products ${ }^{(39)}$, since high levels of methylglyoxal, for example, are highly cytotoxic. Surprisingly, the physiological role of dicarbonyls including methylglyoxal is still rather obscure (methylglyoxal is known to target several proteins involved in the regulation of cell growth, differentiation and cell death). From an evolutionary point of view monosaccharides such as glucose have evolved as a universal source of energy and $\mathrm{C}$ for metabolism; however, because of their intrinsically-high reactivity with amines, non-enzymic glycation is an unavoidable 'background' reaction in all living systems ${ }^{(40)}$. Since uncontrolled glycation is detrimental to the function and integrity of biological macromolecules (the production of ROS from early glycation products, impairment of enzyme functions, perturbations of peptide hormone signalling, activation of AGE-specific receptors, cross-linking of structural proteins, impairment of protein recycling, mutagenicity etc.; see later) the need for regulatory systems capable of limiting and reversing such protein modifications has evolved in parallel ${ }^{(40)}$. Passive regulatory mechanisms to limit unwanted excessive glycation include preference for monosaccharides with the lowest reactivity towards amines (i.e. glucose) and the maintenance of the lowest glycaemia possible or necessary as a result of prompt disposal of excess glucose to storage forms under insulin regulation. However, exclusively active mechanisms (deglycating enzyme systems) can (at least partly) maintain homeostasis when there are physiological or pathophysiological variations in the levels of glycating substrates. One of these detoxification mechanisms is the glyoxalase system $^{(41)}$. Methylglyoxal reacts spontaneously with glutathione to form a hemithioacetal, which is converted into S-D-lactoylglutathione by glyoxalase I, and then further metabolised to D-lactate by glyoxalase II. The importance of methylglyoxal and its detoxification in hyperglycaemia has been confirmed experimentally; glyoxalase I overexpression in vitro completely protects against the hyperglycaemiadriven formation of methylglyoxal and AGE in bovine endothelial cells ${ }^{(42)}$. Similarly, fructoselysines may be enzymically degraded by fructosamine-3-kinase $(\mathrm{FN} 3 \mathrm{~K})^{(32,33)}$. FN3K phosphorylates fructoselysine residues on glycated proteins yielding fructosamine 3-phosphates, which are unstable and spontaneously decompose to form 3deoxyglucosone. Based on current knowledge of both these enzymic systems (and several others such as aldehyde reductases and dehydrogenases and amadoriase) it is clear that deglycation plays a regulatory role under the normal metabolic conditions and efficacy of the systems may, consequently, play an important role in hyperglycaemia ${ }^{(43)}$. Whether the genetic variability in the glyoxalase and FN3K loci influence their efficacy will be discussed later (p. 68).

\section{Biological effects of advanced glycation end products}

AGE exert multiple biologically-important effects in living organisms by direct modification of proteins (and their functions) and indirectly via AGE-binding receptors. The importance of direct glycation certainly applies to longlived proteins such as extracellular matrix proteins (e.g. collagen); their cross-linking (lysine to lysine or lysine to arginine residues), rigidity and resistance to proteolysis contribute to the changes in physical properties observed during aging, with accelerated rates in tissues (e.g. skin collagen) from patients with diabetes ${ }^{(44)}$. If glycation occurs at specific sites it can also affect the cell-collagen interaction, e.g. modification of arginine within the RGD or GFOGER motifs recognised by integrins $\alpha 1 \beta 2$ and $\alpha 2 \beta 1$, which reduces cell interactions during turnover and platelet interactions and can ultimately affect tissue repair and wound healing in patients with diabetes ${ }^{(45)}$. Argininederived hydroimidazolone modification of integrin-binding sites of vascular-basement-membrane type IV collagen has been shown to induce endothelial cell detachment, anoikis and inhibition of angiogenesis, therefore possibly contributing to vascular damage in diabetes ${ }^{(46)}$. In proteins with a faster turnover abnormal protein-protein 
or enzyme-substrate interactions can be affected by glycation. The most-abundant plasma protein in man, human serum albumin, is an important target of glycation in vivo. Peptide mapping of human serum albumin has identified hot spots for glycation by dicarbonyls (methylglyoxal) located in the drug-binding site and the active site of albumin-associated esterase activity ${ }^{(47)}$; hot spots for modification by glucose have also been identified ${ }^{(48)}$. Similar hot spots for dicarbonyl-derived arginine-directed modification (in addition to glucose-derived lysine-directed modification) have been identified in $\mathrm{Hb}^{(49)}$, both types of modifications have been shown to contribute to increased susceptibility to auto-oxidation, reduced $\alpha$-helix content, increased thermolability and a weaker haem-globin linkage in glycated $\mathrm{Hb}^{(50)}$. These examples are just some of the glycated proteins studied; structural modification of many other proteins (such as apo, extracellular matrix proteins, crystalline etc.) also contributes to diabetic pathology. Another interesting effect of AGE has come from an in vitro study demonstrating that AGE dose-dependently impairs CD34 + progenitor cell function (i.e. incorporation of progenitor cells into the sprouting endothelium), which might be yet another pathophysiological factor (mediated by a hitherto unknown mechanism) of disturbed vascular function in diabetes ${ }^{(51)}$.

Although most of the research has focused on the effect of AGE on proteins, it has become increasingly obvious that DNA serves as another target for AGE modification. The genotoxicity of AGE has been documented in vitro in several cell lines ${ }^{(52,53)}$ and in vivo in patients with uraemia who are undergoing different types of haemodialysis ${ }^{(54)}$. DNA damage is induced by both the production of ROS via receptor-mediated signalling, probably involving the receptor for $\mathrm{AGE}(\mathrm{RAGE}) / \mathrm{NAD}(\mathrm{P}) \mathrm{H}$ oxidase pathway (estimated by 8-hydroxy-2-deoxyguanosine), and by the direct effect of AGE on DNA producing base modifications, stand breaks, photosensitisation and apurination or apyrimidination.

Circulating AGE-modified molecules also interact with specific cell-surface receptors on a range of cell types (in the circulation predominantly on monocytes and macrophages and endothelium). In some cases AGE undergo endocytosis and degradation, in others they activate intracellular signalling pathways and influence cellular phenotype. Several types of receptors for AGE-modified molecules have been identified: $\operatorname{RAGE}^{(55,56)}$; galectin- $3^{(57)}$; OST-48; 80K-H ${ }^{(58)}$; scavenger receptors class A (I and II) ${ }^{(59)}$ and $\mathrm{B}$ (CD36 and BI); lectin-like oxidised LDL receptor-1; FEEL-1 and -2; probably others as yet unidentified $^{(60)}$. RAGE, isolated and characterised in $1992^{(55,61)}$, is an Ig-type cell-surface receptor that recognises the tertiary structure of multiple ligands including S100/calgranulins ${ }^{(62)}$ and high-mobility-group box-1 protein $^{(63)}$, amyloid $\beta$-peptides ${ }^{(64)}$ and AGE. RAGE has similarities with signalling pattern-recognition receptors such as Toll-like or mannose-receptors that are expressed by immune cells and recognise proteins associated with microbial pathogens or cellular stress and participate predominantly in the innate immune response. Accumulating experimental data on RAGE functions and actions have been extensively reviewed throughout the past decade, particularly in the most recent comprehensive reviews ${ }^{(65-68)}$. Binding of AGE to RAGE has been shown to activate several intracellular signal transduction pathways (probably tissue- and cell-type-specific), mainly mitogen-activated protein kinases including extracellular regulated kinase $1 / 2$, p38 mitogen-activated protein kinase and stress-activated protein kinase/c-Jun N-terminal kinase; furthermore, other pathways identified are the janus kinase/signal transducers and activators of transcription pathway, 1-phosphatidylinositol 3-kinase and $\mathrm{NAD}(\mathrm{P}) \mathrm{H}$ oxidase. As AGE-RAGE signalling is probably cell-type and ligand specific, the array of cellular and tissue responses has to be quite broad. One of the well-described down-stream events following activation of upstream kinases by AGE ligation to RAGE is $N F-\kappa B$ activation. Unlike the physiological transient NF- $\kappa \mathrm{B}$ activation promoting cell survival under a variety of stimuli, in diabetes (in vivo in mononuclear cells from patients with T1DM as well as in vitro) $\mathrm{NF}-\kappa \mathrm{B}$ activation has been shown to be sustained over long-term periods as a result of overproduction of the NF- $\mathrm{B}$ p 65 subunit, while at the same time degradation of the inhibitory subunit of $N F-\kappa B$ is increased $^{(69)}$. Considerable data relating to the actions of RAGE have been generated using blockade of signalling by soluble RAGE, transfection of cells with a dominant negative RAGE plasmid or transgenic mice expressing RAGE tissue-specifically or RAGE-deficient mice. Interestingly, RAGE also exists in vivo in a soluble form similar to other secreted pattern-recognition receptors (such as pentraxins, mannan-binding lectin etc.). There have been several independent descriptions of the existence of endogenous RAGE variants derived by alternative splicing of the gene leading to $\mathrm{C}$ - or N-terminal truncation ${ }^{(70-72)}$. A proportion of the RAGE isoforms produced is tissuespecific, regulated by as yet unknown mechanisms. Circulating C-terminally-truncated soluble RAGE of approximately $50 \mathrm{kDa}$ produced by endothelial cells is regarded as a naturally-occurring competitive inhibitor of signalling pathways induced by the transmembrane RAGE. Following the discovery of soluble RAGE, decreased levels have been demonstrated in several diseases in association with enhanced formation of AGE, such as coronary disease ${ }^{(73)}$, carotid and femoral atherosclerosis ${ }^{(74)}$, essential hypertension ${ }^{(75)}$, diabetic retinopathy ${ }^{(76,77)}$, rheumatoid arthritis ${ }^{(78)}$ and Alzheimer's disease ${ }^{(79)}$.

\section{The 'second' hit: decreased excretion of advanced glycation end products}

\section{Processing and metabolism of advanced glycation end products}

The integrity of the cellular proteome is maintained by rapid proteolysis of misfolded or altered proteins by the proteasome ${ }^{(80)}$. Proteasomes are large protein complexes that are located in the nucleus and cytoplasm of all eukaryotes. They can function as the $26 \mathrm{~S}$ proteasome, which comprises one $20 \mathrm{~S}$ core particle and two 19S regulatory caps that carry out ubiquitin- and ATP-dependent proteolysis, or as the $20 \mathrm{~S}$ proteasome alone. Oxidised proteins are degraded directly by the $20 \mathrm{~S}$ core particle 


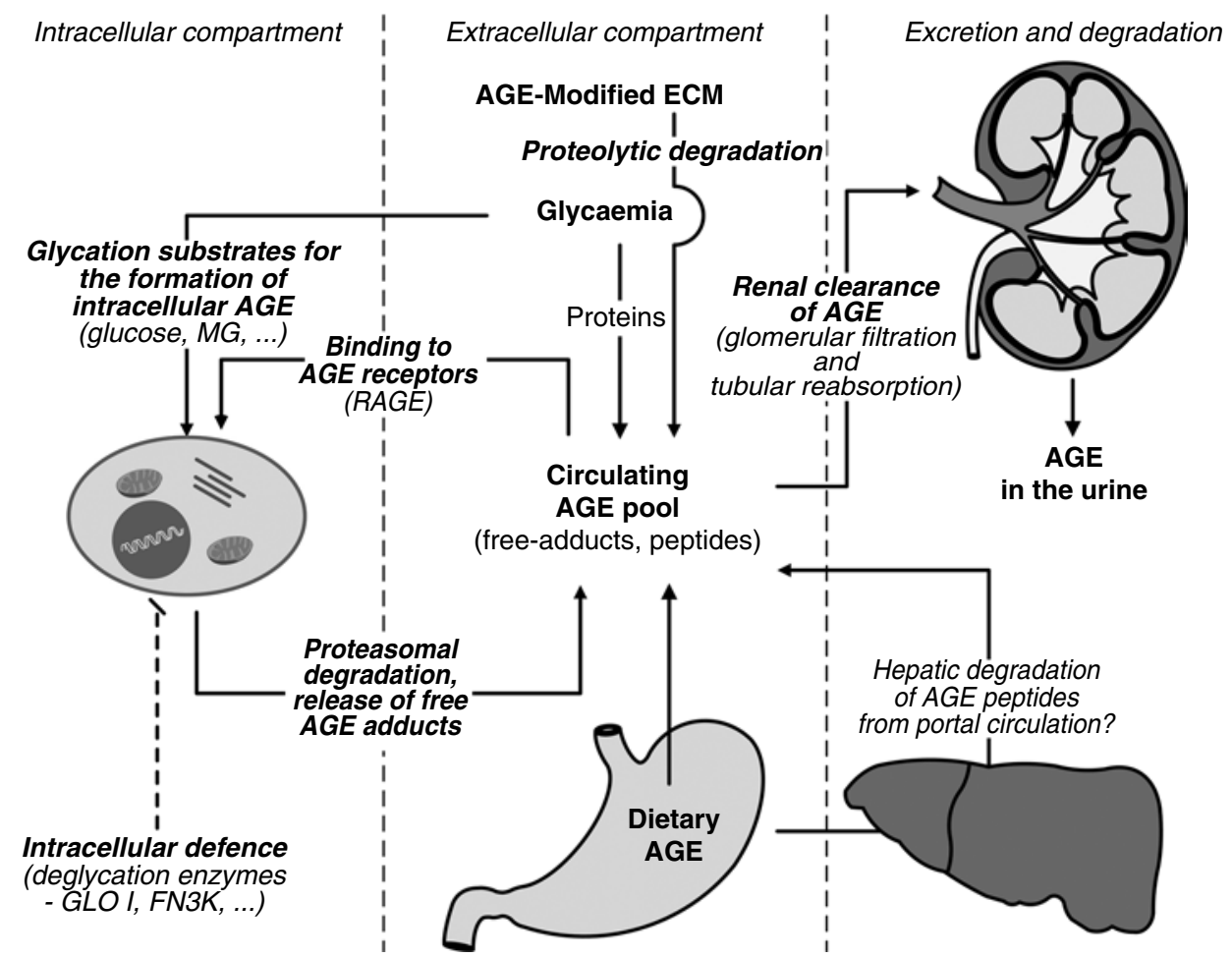

Fig. 1. Overview of advanced glycation end product (AGE) metabolism and factors influencing AGE turnover and the concentration of AGE in particular body compartments. MG, methylglyoxal; GLO I, glyoxalase I; FN3K, fructosamine 3 kinase; RAGE, receptor of AGE; ECM, extracellular matrix.

without the involvement of the $19 \mathrm{~S}$ regulatory cap and do not require ATP hydrolysis or tagging with ubiquitin ${ }^{(81)}$. Cellular proteins modified by AGE are also subject to intracellular proteolytic degradation, releasing free AGE into the circulation (i.e. AGE-free adducts) ${ }^{(22)}$, and are probably the most important source of AGE in circulation, even if cellular glycated proteins exhibit some extent of resistance to proteasome degradation ${ }^{(82)}$. In vitro glyoxal treatment of fibroblasts inhibits $20 \mathrm{~S}$ proteasome peptidase activities without changing the proteasome content ${ }^{(82)}$. Additionally, a decrease in proteasome degradation can be, to some extent, a result of AGE modification of lysine residues that are then inaccessible for ubiquitinylation or glycation by the proteasome itself ${ }^{(83,84)}$.

In the circulation the total pool of AGE consists of those bound to polypeptides (i.e. formed primarily on plasma proteins), peptides (probably released by extracellular proteolysis from tissue-immobilised AGE) and amino acids (formed by proteolytic degradation of intracellular proteins, direct modification of circulating amino acids and by exogenously-derived AGE, primarily those contained in food and absorbed from the intestine; see Fig. 1). The nomenclature of AGE in the context of their metabolism therefore distinguishes between (1) glycation adduct residues of proteins, (2) glycation adduct residues of peptides $(0 \cdot 5-12 \mathrm{kDa})$ and (3) glycation-free adducts (amino acids). The latter category represents the most abundant form of AGE in the plasma of healthy subjects as well as subjects with diabetes ${ }^{(35)}$.

\section{Role of the kidney in the excretion of advanced glycation end products}

Renal clearance is the predominant means of excretion of AGE, particularly the low-molecular-weight fraction (glycation-free adducts) ${ }^{(35)}$. The predominant plasma AGE (hydroimidazolones, $\mathrm{N}_{\varepsilon}$-carboxymethyl-lysine (CML) and $\mathrm{N}_{\varepsilon}$-carboxyethyl-lysine) have a high renal clearance ${ }^{(22)}$ and their levels are inversely correlated with renal function ${ }^{(85)}$. AGE adducts and peptides are filtered into the glomeruli and a small proportion may be reabsorbed and degraded by proximal tubular cells ${ }^{(86)}$. Subjects with chronic renal failure have increased plasma levels of glycationfree adducts (fructoselysine, methylglyoxal-H, CML and $\mathrm{N}_{\varepsilon}$-carboxyethyl-lysine) compared with normal controls ( $\leq 5$-fold); however, in patients with end-stage renal disease and renal replacement therapy plasma glycation free adducts are increased $\leq 18$-fold on peritoneal dialysis and $\leq 40$-fold on haemodialysis ${ }^{(87)}$. AGE accumulate in patients with uraemia to a much greater extent than in subjects with normal renal function ${ }^{88-91)}$; however, AGE do not differ between patients with uraemia associated with diabetes and those with uraemia not associated with diabetes ${ }^{(92,93)}$. Renal replacement therapy itself also plays a role; the concentration of AGE in the peritoneal dialysate exceeds that of the plasma, suggesting that AGE might be formed de novo in the peritoneal cavity from the glucose and its derivatives formed during heat sterilisation of the dialysate ${ }^{(27)}$. The origin of increased AGE in uraemia is 
complex and not entirely dependent on their decreased renal clearance; it is more likely to be a consequence of enhanced oxidative and carbonyl stress and inflammation induced by uraemic toxins and contact with dialysis membranes and fluids ${ }^{(94,95)}$.

The involvement of the liver in the removal of AGE has also been studied, as preliminary experimental data for animals injected with heavily-modified albumin indicate hepatic uptake by scavenger receptors and metabolism of $\mathrm{AGE}^{(96,97)}$. Similarly, elevation of AGE in subjects with liver cirrhosis and subsequent normalisation after liver transplantation has been demonstrated $^{(98)}$. However, extraction of AGE formed in vivo (minimally modified compared with the previous experiments) from the blood entering and leaving the liver of both healthy subjects and patients with liver cirrhosis does not suggest marked hepatic degradation ${ }^{(99)}$.

\section{Aetiology of chronic renal failure and end-stage renal disease, diabetic nephropathy}

Diabetic nephropathy is a serious long-term consequence of diabetes that affects approximately $30 \%$ of patients with T1DM and T2DM, and it is the major single cause of chronic kidney disease and end-stage renal disease in developed countries (approximately 28\%). Other diseases leading to chronic kidney disease and end-stage renal disease include hypertension (approximately 24\%), glomerulonephritis $(21 \%)$ and several less-common diseases such as polycystic kidney disease, chronic pyelonephritis, nephrolithiasis and systemic lupus erythematosus.

The aetiology of diabetic nephropathy comprises both the metabolic and haemodynamic changes that accompany diabetes $^{(100)}$. The principal metabolic changes associated with hyperglycaemia have been described earlier (pp. 6162). Haemodynamic changes are represented initially by increased intraglomerular pressure, which is independent of systemic blood pressure and can be detected quite early after the onset of the disease. Blockade of the renninangiotensin system (by angiotensin-converting enzyme inhibitors and/or angiotensin II receptor blockers) has been convincingly shown to delay the onset and progression of diabetic nephropathy, not only by its effect on filtration pressure but also by its non-haemodynamic effects (suppression of ROS production and cytokine release $)^{(100-103)}$. All parts of nephron (the vasculature, glomerular filtration barrier, tubuli and also the kidney interticium) undergo pathological changes during the course of diabetic nephropathy. Experimental data (mainly from animal studies using inhibitors of advanced glycation) suggest that the pathogenic mechanism in the diabetic kidney is mainly mediated by $\mathrm{AGE}^{(104)}$. Direct modification of renal proteins by AGE may produce changes in charge selectivity, solubility, conformation (e.g. type IV collagen of glomerular basement membrane and its interaction with podocytes via integrins) and cell turnover (mesangium). Moreover, AGE also interact with specific receptors and binding proteins to influence the renal expression of growth factors and cytokines implicated in the progression of diabetic renal disease. Immunohistochemical data obtained from human or rodent kidneys show that RAGE is expressed by podocytes (but not in mesangial cells or glomerular endothelium) ${ }^{(105)}$ and by proximal tubular cells ${ }^{(106)}$. In rodent models activation of RAGE contributes to glomerular pathology (enhanced permeability, inflammation and glomerular basement membrane thickening), mesangial expansion and tubular changes ${ }^{(106-110)}$. Engagement of RAGE by AGE (and probably also S100/ calgranulins) in the diabetic kidney contributes through the cascade of signalling events using ROS as secondary messengers in the activation of transforming growth factor $\beta$, connective tissue growth factor and vascular endothelial growth factor axes directly responsible for renal remodelling. Experimental blockade of AGE formation by benfotiamine $^{(111)}$, pyridoxamine ${ }^{(112)}$ and alagebrium ${ }^{(113,114)}$, blockade of RAGE by neutralising antibodies ${ }^{(115)}$ or the absence of the latter in RAGE-knock-out mice ${ }^{(107)}$ completely suppress structural and functional changes associated with diabetic nephropathy, thereby supporting the pathogenic role of AGE-RAGE interaction in diabetic nephropathy.

\section{The third hit: increased intake of exogenous advanced glycation end products in the diet}

\section{Maillard reaction; dietary advanced glycation end products sources}

In 1912 the French scientist Louis Camille Maillard described the 'browning' or Maillard reaction between reducing sugars and amino acids during cooking ${ }^{(116)}$. Products formed by this reaction (Maillard reaction products) contribute to the qualitative properties of foods such as colour, taste and aroma; moreover, it has become increasingly evident that they can also affect the nutritional and toxicological properties of food. The potential biological effect of endogenously-formed AGE, especially in situations like diabetes or uraemia, has also stimulated intensive interest in the potential contribution of dietary AGE to an individual's total AGE levels. Thermal processing of foods enhances their digestibility, sensory properties and shelf life, producing microbiologically-safe products with the desired nutritional quality that make a major contribution to the human diet. Although such treatment can lead to the formation of components with presumably healthpromoting properties (such as antioxidants or melanoidins), it can also lead to the formation of potentially-harmful compounds (such as heterocyclic amines, acrylamide and Maillard reaction products) ${ }^{(117)}$. It is clear that food is a rich source of pre-AGE (mainly fructoselysine) and AGE (mainly methylglyoxal-H, CML, pyrraline, pentosidine). Most dietary AGE are derived from sugar- and protein-rich cooked foods such as bakery products, roasted meat, milk and some other drinks (coke drinks, for example, have a lower AGE content than untreated milk, and the AGE content of milk further increases during pasteurisation and sterilisation $\left.{ }^{(118)}\right)$, although, the levels depend also on the preparation conditions, presence of metals and water content ${ }^{(119)}$. Qualitative and quantitative assessment of AGE in food is currently an important area of food research $^{(120)}$. 


\section{Bioavailability, metabolic fate and excretion of dietary advanced glycation end products}

It seems that highly-glycated proteins (containing fructoselysines and AGE) may not be digested efficiently (resistance to proteolysis) and that the majority of AGE present in foods are not absorbed from the gastrointestinal tract but excreted in the faeces. More precisely, approximately $10-30 \%$ of the ingested AGE are intestinally absorbed, mainly in the form of glycation-free adducts and peptides, and are subsequently found in the circulation $^{(121-123)}$, where the peptides undergo rapid degradation to free adducts, as shown by comparing the concentration of glycated peptides in the portal and systemic venous circulation $^{(99)}$. Absorbed AGE are excreted rapidly in the urine by subjects or experimental animals with normal renal function, as indicated by balance studies quantifying recovery in the urine of CML, pyrraline and pentosidine from different foods or after injection of labelled compounds ${ }^{(123-126)}$. In these studies $\leq 80 \%$ of AGE were recovered in the urine, predominantly in the glycation-free adduct form, although it may have been as low as $2 \%$ in the case of protein-bound AGE (e.g. pentosidine in the free adducts in brewed coffee $v$. that of pretzel sticks). In animal studies faecal excretion was reported to be $\leq 26-29 \%$ for CML but only $1-3 \%$ for fructosely$\operatorname{sine}^{(122,123)}$, which was considered to be an effect of the metabolisation of fructoselysine by colon microflora, e.g. Escherichia coli can degrade fructoselysine to glucose 6-phosphate and utilise it as a substrate ${ }^{(127)}$. It is not clear whether AGE are similarly degraded by colon microflora ${ }^{(128)}$.

It is difficult to interpret the findings of both animal and human studies of the bioactivity of AGE because of a series of confounding factors, experimental (study design, duration of administration, medical condition of subjects studied, species studied etc.) as well as methodological (different composition and preparation of high-AGE diet, analytical methods employed to quantify AGE etc.). While some studies have shown a significant effect of dietary AGE, other studies have not found such an effect (see following discussion). Nevertheless, such disparity certainly stimulates further carefully-designed experiments.

\section{Bioactivity of dietary advanced glycation end products: animal studies}

The biological effects of dietary AGE have been investigated in healthy rodents fed isoenergetic chow with different AGE contents (for study periods ranging from 6 weeks to 6 months). Rats on a high-AGE diet have been reported to show a higher increase in plasma AGE, urinary excretion of AGE, weight gain, renal protein excretion and renal expression of the pro-fibrotic cytokine transforming growth factor $\beta^{(129)}$, while, increased fasting plasma insulin has been detected in mice ${ }^{(130)}$.

Similar findings have been obtained in studies of mice with diabetes (non-obese or $\mathrm{db} / \mathrm{db}$ ) fed a high-AGE diet (higher plasma AGE, weight gain and fasting plasma insulin) ${ }^{(131)}$, as well as in another study in which there was also progressive development of diabetic nephropathy (higher urinary AGE excretion, renal protein excretion, glomerular hypertrophy, mesangial expansion and expression of transforming growth factor $\beta$ ) and shorter survival (non-obese NOD mice) ${ }^{(132)}$. A low-AGE diet has also been found to delay the onset of diabetes in diabetic (NOD) mice ${ }^{(133)}$, improve wound healing in $\mathrm{db} / \mathrm{db}^{\mathrm{mice}} \mathrm{m}^{(134)}$ and delay the progression of atherosclerosis ${ }^{(135)}$. In the latter study genetically-hypercholesterolaemic (apoE-deficient) mice fed a low-AGE diet for 4 weeks following experimental injury of the femoral artery were reported to develop a lesser extent of neointimal formation (scar tissue) than animals fed a high-AGE diet ${ }^{(135)}$. Moreover, in the same animal model rendered diabetic by treatment with streptozotocin, 2-month dietary AGE restriction was associated with lower serum AGE, reduced formation of atheromatous lesions, lower tissue expression of AGE receptors and infiltration with inflammatory cells without concomitant differences in plasma glucose, TAG or cholesterol $^{(136)}$

The effect of dietary AGE on renal function has been studied using an experimental model of renal failure (subtotally-nephrectomised rats). Nephrectomised rats were found to exhibit higher weight gain, proteinuria, kidney hypertrophy and expression of transforming growth factor $\beta$ than healthy rats ${ }^{(129)}$. Administration of alagebrium (AGE breaker) was shown to delay and/or reverse established diabetic nephropathy in $\mathrm{db} / \mathrm{db}$ mice by reducing systemic AGE and facilitating their urinary excretion ${ }^{(137)}$. Of particular interest is a study designed to elucidate the potential effect of AGE as a secondary renal insult in rats with a developmental nephron deficit. A low-protein diet fed to female rats during pregnancy and lactation was found to reduce nephron number in their offspring compared with that of the offspring of female rats fed a normal-protein diet; however, no obvious differences were found in systemic blood pressure or glomerular filtration rate. Administration of AGE for 4 weeks beginning at the 20th week of age was shown to induce greater expression of the genes encoding transforming growth factor $\beta$ and procollagen III as well as renal accumulation of AGE when compared with rats with a normal nephron status ${ }^{(138)}$.

\section{Bioactivity of dietary advanced glycation end products: human studies}

In a study of ninety healthy subjects AGE intake (assessed by $3 \mathrm{~d}$ food records) was shown to be correlated with circulating AGE, AGE-modified LDL and high-sensitivity C-reactive protein (CRP) concentrations ${ }^{(139)}$. In a larger study of 172 healthy subjects of different ages it was found that AGE are directly influenced by dietary intake (independent of age or energy intake), and circulating AGE (CML and methylglyoxal derivatives) are elevated in older subjects and correlated with indicators of inflammation and oxidative stress across all ages ${ }^{(140)}$. A 6-week nutritional intervention study of subjects with diabetes has demonstrated that circulating AGE can be modulated by altering dietary AGE intake, and high AGE intake is associated with higher levels of inflammatory molecules $(\mathrm{CRP}, \mathrm{TNF} \alpha)$ and markers of endothelial dysfunction 
(vascular-cell adhesion molecule 1) ${ }^{(141)}$. Furthermore, a comparison of the effects of low and high intakes of dietary AGE on the modification of plasma LDL in patients with diabetes who had equal glycaemic control and lipidaemia has shown that high AGE intake can transform circulating macromolecules to a much greater extent and render them more pro-atherogenic than those of subjects on a low AGE intake ${ }^{(142)}$. Also, a high-AGE diet was found to induce more pronounced micro- and macrovascular dysfunction and endothelial dysfunction compared with a low-AGE diet in a cross-over study with twenty subjects with T2DM ${ }^{(143)}$. The same effect (impaired flow-mediated macrovascular dilatation and endothelial dysfunction) was observed in a study in which forty-four subjects with T2DM and ten subjects without diabetes were administered a single oral AGE challenge ${ }^{(144)}$.

When subjects with chronic renal insufficiency were assigned to either a high- or low-AGE diet the low intake was found to be associated with a decrease in AGE, CRP, plasminogen-activator inhibitor-1, vascular-cell adhesion molecule 1 and TNF $\alpha$ levels ${ }^{(145)}$. The importance of this finding is not clear, however, as a large cross-sectional study of $>300$ patients on haemodialysis that analysed the relationships between AGE and CRP and all-cause as well as cardiovascular mortality has shown better survival of subjects with high total serum fluorescent AGE and CML levels despite higher levels of inflammation markers $(\mathrm{CRP})^{(146)}$. The authors suggest that high serum AGE in patients on haemodialysis with better survival is either an epiphenomenon or reflects a better nutritional status. An inverse relationship between circulating AGE and glomerular filtration rate has also been reported for subjects with T1DM as well for subjects without diabetes ${ }^{(85,147)}$; however, a correlation with inflammatory markers was only present in subjects with diabetes. An even larger study that followed 450 subjects with T2DM and diabetic nephropathy for 2.6 years has ruled out serum CML level as an independent risk factor for cardiovascular or renal outcomes ${ }^{(148)}$.

Interesting findings have been reported from a study of plasma AGE in vegetarians compared with subjects on a typical Western diet. Vegetarians were found to have unexpectedly higher plasma AGE, although not in association with typical AGE toxicity such as induction of insulin resistance (glycaemia), nephrotoxicity (glomerular filtration rate) or inflammation $(\mathrm{CRP})^{(149)}$. On further investigation of the components of the metabolic syndrome in vegetarians and omnivores ${ }^{(150)}$, the authors have proposed that this finding might be the result of a higher intake of fructose (in fruit), which is a better glycating agent that glucose, and that the potential AGE toxicity may be counterbalanced by higher levels of antioxidants often detected in vegetarians.

\section{Advanced glycation end products $v$. (nutri)genomics and (nutri)genetics}

One of the greatest changes preceding and accompanying the current increase in complex diseases has been the change in the human diet, its quality as well as its quantity.
Beyond the role of diet as an energy source, micronutrients (vitamins, $\mathrm{Ca}, \mathrm{Fe}$ etc.) and macronutrients (NEFA, cholesterol, glucose) are potent environmental signals that influence cellular metabolic programming, homeostasis and gene expression. Nutrigenomics is a relatively new discipline that seeks to provide an understanding of how nutrients affect gene expression ${ }^{(151)}$, and studies of the effect of dietary AGE are no exception. Experiments performed in vitro with food-derived AGE have confirmed their potent effect, and the previously observed biological effects of AGE could theoretically also apply to foodderived AGE. AGE derived from common thermallyprocessed foods (animal products, vegetables, starches) have been studied in vitro before ingestion and have been shown to possess pro-oxidative (depletion of reduced glutathione, cross-link formation), pro-inflammatory (induction of $\mathrm{TNF} \alpha$ ) and signalling properties in endothelial cells (human umbilical vein endothelial cells) ${ }^{(152)}$. Another study has investigated the effect of food compounds formed by heat treatment during processing of food on the expression of the RAGE and p44/42 mitogen-activated protein kinase activation ${ }^{(153)}$. Dose-dependent activation of RAGE signal transduction pathways was found in response to food-derived AGE and other thermally-produced compounds, as well as inhibition of this activation by preincubation with anti-RAGE antibody or in cells expressing C-terminally-truncated RAGE. Nevertheless, because of the limited bioavailability of AGE the true effect of foodderived AGE is probably minor in healthy subjects, although definitely worthy of further investigation in vulnerable groups such as infants and patients with diabetes, uraemia and bowel disease.

Another important issue is to understand how genetic variability in relevant genes modulates the effect of dietary components on specific phenotypes, which is the working definition of nutrigenetics. The current human genome has evolved under environmental influences that were, until recently, predominantly harsh rather than hospitable. The resulting metabolic 'thriftiness' is therefore a logical outcome, but undesirable against a background of affluence. Some of the best examples of the nutrigenetic consequences come from lipid metabolism, i.e. how genetic polymorphisms in genes encoding proteins involved in lipoprotein metabolism modulate the effect of dietary lipid intake on plasma lipid levels or the response to lipidlowering interventions. In the context of both endogenously-formed AGE and food-derived AGE genes with potential (nutri)genetic importance are (1) those encoding enzymes detoxifying AGE and their precursors (e.g. glyoxalase system or FN3K) and (2) those encoding AGEbinding scavenger and signalling receptors (e.g. RAGE, galectin-3 etc.). The former group, i.e. genetic variability in deglycating enzymes resulting in their functional variability, could contribute to the observed inter-individual variation in AGE levels that was found in a study of twins without diabetes ${ }^{(154)}$. Approximately $74 \%$ heritability of AGE levels (assessed by serum CML) was found, which was independent of heritability of fasting glucose or $\mathrm{HbA}_{1 \mathrm{c}}$. The notion that genetic factors play an important role in determining AGE levels in the healthy state further emphasises their pathophysiological potential in diseases. 
However, in a study of the common polymorphism A111E in the glyoxalase I in diabetic nephropathy no significant association has been found ${ }^{(155)}$. The activity of another important deglycating enzyme, FN3K, has been shown to exhibit a wide inter-individual variability influenced by the two polymorphisms in the FN3K gene ${ }^{(156)}$. Neither enzyme activity nor frequency of the two gene variants was found to differ between groups of subjects with T1DM and without diabetes, although the relationship with diabetes complications was not studied.

The author's group has been involved in the study of genetic variability in the RAGE gene since soon after its discovery, and together with others has contributed to the identification of several common polymorphisms in the RAGE ${ }^{(157)}$ and some of their potentially interesting phenotypic outcomes, e.g. circulating levels of selected non-enzymic antioxidants ${ }^{(158)}$. Of special interest is the modulation by certain genetic variants in RAGE of the genetic risk of the development of diabetic nephropathy in patients with diabetes, since diabetic nephropathy increases the already-enhanced AGE formation by impairment of their excretion. Using relatively novel approaches to genetic epidemiology suitable for studying complex phenotypes (e.g. haplotype analysis and multi-locus association studies) it has been shown that risk variants in the RAGE gene increase the susceptibility to diabetic nephropathy and accelerate its onset $^{(155,159)}$. Other studies have also identified RAGE variants as risk factors for diabetic nephropathy ${ }^{(160,161)}$.

\section{Conclusions: the double-hit or, alternatively, triple-hit hypothesis in diabetes mellitus?}

Glycation represents the most common type of posttranslation modification of protein residues. Methylglyoxal-derived hydroimidazolones are the most abundant AGE both as protein residues and free adducts. AGE formation is increased as a consequence of hyperglycaemia in diabetes. Cells contain enzymic systems to detoxify precursors of AGE (dicarbonyls and fructosamines) and functional insufficiency of these systems (e.g. as a result of genetic factors) can be of critical importance. AGEmodified proteins are subject to proteasomal degradation, free adducts are released from cells into the plasma and, under normal circumstances, are rapidly excreted in the urine. A decline in renal function, e.g. as a result of diabetic nephropathy, leads to retention of AGE and aggravation of their toxicity, which is mediated by direct modification of macromolecules by AGE and also through their binding to the cell surface receptors (RAGE and others). The resulting increase in the expression of proinflammatory genes contributes to the development of diabetes complications including diabetic nephropathy. A vicious cycle may then ensue whereby AGE contribute to the development of renal impairment, and once developed renal impairment may then contribute to further accumulation of AGE. Although there have been few studies of the biological effects of dietary AGE, current knowledge indicates that the impact of dietary AGE is relatively low in metabolically-healthy subjects with preserved renal function, because limited bioavailability means that AGE intake represents only a minor contribution compared with endogenously-produced AGE. However, in selected groups such as patients with diabetes (especially those with diabetic nephropathy) and uraemia AGE-rich diet can further aggravate AGE-mediated pathology.

In conclusion, accumulation of AGE is intimately associated with the chronic course of diabetes and represents an example of a self-amplifying pathophysiological mechanism. The data presented support the proposal that AGE act as a multiple-hit agent; although further studies are needed to assess their impact more precisely.

\section{Acknowledgements}

The author thanks the Grant Agency of the Czech Academy of Sciences (KJB501620601) and the Ministry of Health of the Czech Republic (NR 9443-3/2007) for the support of her work.

\section{References}

1. King H, Aubert RE \& Herman WH (1998) Global burden of diabetes, 1995-2025. prevalence, numerical estimates, and projections. Diabetes Care 21, 1414-1431.

2. Brownlee M (2001) Biochemistry and molecular cell biology of diabetic complications. Nature 414, 813-820.

3. Du X, Edelstein D, Obici S, Higham N, Zou MH \& Brownlee M (2006) Insulin resistance reduces arterial prostacyclin synthase and eNOS activities by increasing endothelial fatty acid oxidation. J Clin Invest 116, 10711080.

4. Ahmed N \& Thornalley PJ (2007) Advanced glycation endproducts: what is their relevance to diabetic complications? Diabetes Obes Metab 9, 233-245.

5. Ahmed N (2005) Advanced glycation endproducts - role in pathology of diabetic complications. Diabetes Res Clin Pract 67, 3-21.

6. Stitt AW \& Curtis TM (2005) Advanced glycation and retinal pathology during diabetes. Pharmacol Rep 57, Suppl., 156-168.

7. Munch G, Gasic-Milenkovic J \& Arendt T (2003) Effect of advanced glycation endproducts on cell cycle and their relevance for Alzheimer's disease. J Neural Transm 65, Suppl., 63-71.

8. Finot PA (2005) Historical perspective of the Maillard reaction in food science. Ann NY Acad Sci 1043, 1-8.

9. Gaudreault N, Scriven DR \& Moore ED (2004) Characterisation of glucose transporters in the intact coronary artery endothelium in rats: GLUT-2 upregulated by long-term hyperglycaemia. Diabetologia 47, 2081-2092.

10. Kaiser N, Sasson S, Feener EP, Boukobza-Vardi N, Higashi S, Moller DE, Davidheiser S, Przybylski RJ \& King GL (1993) Differential regulation of glucose transport and transporters by glucose in vascular endothelial and smooth muscle cells. Diabetes 42, 80-89.

11. Brosius FC \& Heilig CW (2005) Glucose transporters in diabetic nephropathy. Pediatr Nephrol 20, 447-451.

12. Linden KC, DeHaan CL, Zhang Y, Glowacka S, Cox AJ, Kelly DJ \& Rogers S (2006) Renal expression and localization of the facilitative glucose transporters GLUT1 and GLUT12 in animal models of hypertension and diabetic nephropathy. Am J Physiol Renal Physiol 290, F205-F213. 
13. Brownlee M (2005) The pathobiology of diabetic complications: a unifying mechanism. Diabetes 54, 1615-1625.

14. Nishikawa T, Edelstein D, Du XL et al. (2000) Normalizing mitochondrial superoxide production blocks three pathways of hyperglycaemic damage. Nature 404, 787-790.

15. Adam-Vizi V \& Chinopoulos C (2006) Bioenergetics and the formation of mitochondrial reactive oxygen species. Trends Pharmacol Sci 27, 639-645.

16. Soriano FG, Virag L \& Szabo C (2001) Diabetic endothelial dysfunction: role of reactive oxygen and nitrogen species production and poly(ADP-ribose) polymerase activation. J Mol Med 79, 437-448.

17. Soriano FG, Pacher P, Mabley J, Liaudet L \& Szabo C (2001) Rapid reversal of the diabetic endothelial dysfunction by pharmacological inhibition of poly(ADP-ribose) polymerase. Circ Res 89, 684-691.

18. Du X, Matsumura T, Edelstein D, Rossetti L, Zsengeller Z, Szabo C \& Brownlee M (2003) Inhibition of GAPDH activity by poly(ADP-ribose) polymerase activates three major pathways of hyperglycemic damage in endothelial cells. J Clin Invest 112, 1049-1057.

19. Sirover MA (2005) New nuclear functions of the glycolytic protein, glyceraldehyde-3-phosphate dehydrogenase, in mammalian cells. J Cell Biochem 95, 45-52.

20. Hara MR, Cascio MB \& Sawa A (2006) GAPDH as a sensor of NO stress. Biochim Biophys Acta 1762, 502-509.

21. Chuang DM, Hough C \& Senatorov VV (2005) Glyceraldehyde-3-phosphate dehydrogenase, apoptosis, and neurodegenerative diseases. Annu Rev Pharmacol Toxicol 45, 269-290.

22. Thornalley PJ, Battah S, Ahmed N, Karachalias N, Agalou S, Babaei-Jadidi R \& Dawnay A (2003) Quantitative screening of advanced glycation endproducts in cellular and extracellular proteins by tandem mass spectrometry. Biochem J 375, 581-592.

23. Vlassara H \& Palace MR (2003) Glycoxidation: the menace of diabetes and aging. Mt Sinai J Med 70, 232-241.

24. Baynes JW \& Thorpe SR (2000) Glycoxidation and lipoxidation in atherogenesis. Free Radic Biol Med 28, 17081716.

25. Munch G, Deuther-Conrad W \& Gasic-Milenkovic J (2002) Glycoxidative stress creates a vicious cycle of neurodegeneration in Alzheimer's disease - a target for neuroprotective treatment strategies? J Neural Transm 62, Suppl., 303-307.

26. DeGroot J (2004) The AGE of the matrix: chemistry, consequence and cure. Curr Opin Pharmacol 4, 301-305.

27. Thornalley PJ (2006) Advanced glycation end products in renal failure. J Ren Nutr 16, 178-184.

28. Rahbar S (1968) An abnormal hemoglobin in red cells of diabetics. Clin Chim Acta 22, 296-298.

29. Pickup JC (2003) Diabetic control and its measurement. In Textbook of Diabetes, 3rd ed., vol. 1, 34.31-34.17 [JC Pickup and G Williams, editors]. Oxford: Blackwell Science.

30. Ahmed N \& Thornalley PJ (2003) Quantitative screening of protein biomarkers of early glycation, advanced glycation, oxidation and nitrosation in cellular and extracellular proteins by tandem mass spectrometry multiple reaction monitoring. Biochem Soc Trans 31, 1417-1422.

31. Hayashi T \& Namiki M (1980) Formation of two-carbon sugar fragments at an early stage of the browning reaction of sugar and amine. Agric Biol Chem 44, 2575-2580.

32. Delpierre G, Rider MH, Collard F, Stroobant V, Vanstapel F, Santos HI \& Van Schaftingen E (2000) Identification, cloning, and heterologous expression of a mammalian fructosamine-3-kinase. Diabetes 49, 1627-1634.
33. Szwergold BS, Howell S \& Beisswenger PJ (2001) Human fructosamine-3-kinase: purification, sequencing, substrate specificity, and evidence of activity in vivo. Diabetes 50, 2139-2147.

34. Beisswenger PJ, Howell SK, Smith K \& Szwergold BS (2003) Glyceraldehyde-3-phosphate dehydrogenase activity as an independent modifier of methylglyoxal levels in diabetes. Biochim Biophys Acta 1637, 98-106.

35. Ahmed N, Babaei-Jadidi R, Howell SK, Beisswenger PJ \& Thornalley PJ (2005) Degradation products of proteins damaged by glycation, oxidation and nitration in clinical type 1 diabetes. Diabetologia 48, 1590-1603.

36. Ahmed N, Babaei-Jadidi R, Howell SK, Thornalley PJ \& Beisswenger PJ (2005) Glycated and oxidized protein degradation products are indicators of fasting and postprandial hyperglycemia in diabetes. Diabetes Care 28, 2465-2471.

37. Beisswenger PJ, Howell SK, O’Dell RM, Wood ME, Touchette AD \& Szwergold BS (2001) alpha-Dicarbonyls increase in the postprandial period and reflect the degree of hyperglycemia. Diabetes Care 24, 726-732.

38. Phillips SA \& Thornalley PJ (1993) The formation of methylglyoxal from triose phosphates. Investigation using a specific assay for methylglyoxal. Eur $J$ Biochem 212, $101-105$

39. Thornalley PJ (2003) The enzymatic defence against glycation in health, disease and therapeutics: a symposium to examine the concept. Biochem Soc Trans 31, 1341-1342.

40. Szwergold BS (2005) Intrinsic toxicity of glucose, due to non-enzymatic glycation, is controlled in-vivo by deglycation systems including: FN3K-mediated deglycation of fructosamines and transglycation of aldosamines. Med Hypotheses 65, 337-348.

41. Thornalley PJ (2003) Glyoxalase I - structure, function and a critical role in the enzymatic defence against glycation. Biochem Soc Trans 31, 1343-1348.

42. Shinohara M, Thornalley PJ, Giardino I, Beisswenger P, Thorpe SR, Onorato J \& Brownlee M (1998) Overexpression of glyoxalase-I in bovine endothelial cells inhibits intracellular advanced glycation endproduct formation and prevents hyperglycemia-induced increases in macromolecular endocytosis. J Clin Invest 101, 1142-1147.

43. Conner JR, Beisswenger PJ \& Szwergold BS (2005) Some clues as to the regulation, expression, function, and distribution of fructosamine-3-kinase and fructosamine3-kinase-related protein. Ann NY Acad Sci 1043, 824-836.

44. Yu Y, Thorpe SR, Jenkins AJ et al. (2006) Advanced glycation end-products and methionine sulphoxide in skin collagen of patients with type 1 diabetes. Diabetologia $\mathbf{4 9}$, 2488-2498.

45. Avery NC \& Bailey AJ (2006) The effects of the Maillard reaction on the physical properties and cell interactions of collagen. Pathol Biol (Paris) 54, 387-395.

46. Dobler D, Ahmed N, Song L, Eboigbodin KE \& Thornalley PJ (2006) Increased dicarbonyl metabolism in endothelial cells in hyperglycemia induces anoikis and impairs angiogenesis by RGD and GFOGER motif modification. Diabetes 55, 1961-1969.

47. Ahmed N \& Thornalley PJ (2005) Peptide mapping of human serum albumin modified minimally by methylglyoxal in vitro and in vivo. Ann NY Acad Sci 1043, 260266.

48. Garlick RL \& Mazer JS (1983) The principal site of nonenzymatic glycosylation of human serum albumin in vivo. J Biol Chem 258, 6142-6146.

49. Gao Y \& Wang Y (2006) Site-selective modifications of arginine residues in human hemoglobin induced by methylglyoxal. Biochemistry 45, 15654-15660. 
50. Sen S, Kar M, Roy A \& Chakraborti AS (2005) Effect of nonenzymatic glycation on functional and structural properties of hemoglobin. Biophys Chem 113, 289-298.

51. Scheubel RJ, Kahrstedt S, Weber H, Holtz J, Friedrich I, Borgermann J, Silber RE \& Simm A (2006) Depression of progenitor cell function by advanced glycation endproducts (AGEs): potential relevance for impaired angiogenesis in advanced age and diabetes. Exp Gerontol 41, 540-548.

52. Stopper H, Schinzel R, Sebekova K \& Heidland A (2003) Genotoxicity of advanced glycation end products in mammalian cells. Cancer Lett 190, 151-156.

53. Schupp N, Schinzel R, Heidland A \& Stopper H (2005) Genotoxicity of advanced glycation end products: involvement of oxidative stress and of angiotensin II type 1 receptors. Ann NY Acad Sci 1043, 685-695.

54. Fragedaki E, Nebel M, Schupp N et al. (2005) Genomic damage and circulating AGE levels in patients undergoing daily versus standard haemodialysis. Nephrol Dial Transplant 20, 1936-1943.

55. Neeper M, Schmidt AM, Brett J, Yan SD, Wang F, Pan YC, Elliston K, Stern D \& Shaw A (1992) Cloning and expression of a cell surface receptor for advanced glycosylation end products of proteins. J Biol Chem 267, 14998-15004.

56. Schmidt AM, Vianna M, Gerlach M, Brett J, Ryan J, Kao J, Esposito C, Hegarty H, Hurley W \& Clauss M (1992) Isolation and characterization of two binding proteins for advanced glycosylation end products from bovine lung which are present on the endothelial cell surface. J Biol Chem 267, 14987-14997.

57. Vlassara H, Li YM, Imani F, Wojciechowicz D, Yang Z, Liu FT \& Cerami A (1995) Identification of galectin-3 as a high-affinity binding protein for advanced glycation end products (AGE): a new member of the AGE-receptor complex. Mol Med 1, 634-646.

58. Li YM, Mitsuhashi T, Wojciechowicz D, Shimizu N, Li J, Stitt A, He C, Banerjee D \& Vlassara H (1996) Molecular identity and cellular distribution of advanced glycation endproduct receptors: relationship of p60 to OST-48 and p90 to 80K-H membrane proteins. Proc Natl Acad Sci USA 93, 11047-11052.

59. Araki N, Higashi T, Mori T, Shibayama R, Kawabe Y, Kodama T, Takahashi K, Shichiri M \& Horiuchi S (1995) Macrophage scavenger receptor mediates the endocytic uptake and degradation of advanced glycation end products of the Maillard reaction. Eur J Biochem 230, 408-415.

60. Horiuchi S, Sakamoto Y \& Sakai M (2003) Scavenger receptors for oxidized and glycated proteins. Amino Acids 25, 283-292.

61. Schmidt AM, Vianna M, Gerlach M, Brett J, Ryan J, Kao J, Esposito C, Hegarty H, Hurley W \& Clauss M (1992) Isolation and characterization of two binding proteins for advanced glycosylation end products from bovine lung which are present on the endothelial cell surface. J Biol Chem 267, 14987-14997.

62. Hofmann MA, Drury S, Fu C et al. (1999) RAGE mediates a novel proinflammatory axis: a central cell surface receptor for S100/calgranulin polypeptides. Cell 97, 889-901.

63. Hori O, Brett J, Slattery T et al. (1995) The receptor for advanced glycation end products (RAGE) is a cellular binding site for amphoterin. Mediation of neurite outgrowth and co-expression of rage and amphoterin in the developing nervous system. J Biol Chem 270, 25752-25761.

64. Yan SD, Chen X, Fu J et al. (1996) RAGE and amyloidbeta peptide neurotoxicity in Alzheimer's disease. Nature 382, 685-691.
65. Yan SF, Barile GR, D’Agati V, Du Yan S, Ramasamy R \& Schmidt AM (2007) The biology of RAGE and its ligands: uncovering mechanisms at the heart of diabetes and its complications. Curr Diab Rep 7, 146-153.

66. Bierhaus A, Humpert PM, Morcos M, Wendt T, Chavakis T, Arnold B, Stern DM \& Nawroth PP (2005) Understanding RAGE, the receptor for advanced glycation end products. $J$ Mol Med 83, 876-886.

67. Hudson BI, Wendt T, Bucciarelli LG, Rong LL, Naka Y, Yan SF \& Schmidt AM (2005) Diabetic vascular disease: it's all the RAGE. Antioxid Redox Signal 7, 1588-1600.

68. Bierhaus A, Stern DM \& Nawroth PP (2006) RAGE in inflammation: a new therapeutic target? Curr Opin Investig Drugs 7, 985-991.

69. Bierhaus A, Schiekofer S, Schwaninger M et al. (2001) Diabetes-associated sustained activation of the transcription factor nuclear factor-kappaB. Diabetes 50, 2792-2808.

70. Malherbe P, Richards JG, Gaillard H, Thompson A, Diener C, Schuler A \& Huber G (1999) cDNA cloning of a novel secreted isoform of the human receptor for advanced glycation end products and characterization of cells coexpressing cell-surface scavenger receptors and Swedish mutant amyloid precursor protein. Brain Res Mol Brain Res 71, 159-170.

71. Schlueter C, Hauke S, Flohr AM, Rogalla P \& Bullerdiek J (2003) Tissue-specific expression patterns of the RAGE receptor and its soluble forms - a result of regulated alternative splicing? Biochim Biophys Acta 1630, 1-6.

72. Yonekura H, Yamamoto Y, Sakurai S et al. (2003) Novel splice variants of the receptor for advanced glycation end-products expressed in human vascular endothelial cells and pericytes, and their putative roles in diabetes-induced vascular injury. Biochem J 370, 1097-1109.

73. Falcone C, Emanuele E, D'Angelo A, Buzzi MP, Belvito C, Cuccia M \& Geroldi D (2005) Plasma levels of soluble receptor for advanced glycation end products and coronary artery disease in nondiabetic men. Arterioscler Thromb Vasc Biol 25, 1032-1037.

74. Koyama H, Shoji T, Yokoyama H et al. (2005) Plasma level of endogenous secretory RAGE is associated with components of the metabolic syndrome and atherosclerosis. Arterioscler Thromb Vasc Biol 25, 2587-2593.

75. Geroldi D, Falcone C, Emanuele E, D'Angelo A, Calcagnino M, Buzzi MP, Scioli GA \& Fogari R (2005) Decreased plasma levels of soluble receptor for advanced glycation end-products in patients with essential hypertension. J Hypertens 23, 1725-1729.

76. Hayaishi-Okano R, Yamasaki Y, Kajimoto Y et al. (2003) Association of $\mathrm{NAD}(\mathrm{P}) \mathrm{H}$ oxidase $\mathrm{p} 22$ phox gene variation with advanced carotid atherosclerosis in Japanese type 2 diabetes. Diabetes Care 26, 458-463.

77. Sakurai S, Yamamoto Y, Tamei H et al. (2006) Development of an ELISA for esRAGE and its application to type 1 diabetic patients. Diabetes Res Clin Pract 73, 158-165.

78. Pullerits R, Bokarewa M, Dahlberg L \& Tarkowski A (2005) Decreased levels of soluble receptor for advanced glycation end products in patients with rheumatoid arthritis indicating deficient inflammatory control. Arthritis Res Ther 7, R817-R824.

79. Emanuele E, D'Angelo A, Tomaino C, Binetti G, Ghidoni R, Politi P, Bernardi L, Maletta R, Bruni AC \& Geroldi D (2005) Circulating levels of soluble receptor for advanced glycation end products in Alzheimer disease and vascular dementia. Arch Neurol 62, 1734-1736.

80. Goldberg AL (2003) Protein degradation and protection against misfolded or damaged proteins. Nature 426, 895899. 
81. Shringarpure R, Grune T, Mehlhase J \& Davies KJ (2003) Ubiquitin conjugation is not required for the degradation of oxidized proteins by proteasome. J Biol Chem 278, 311318.

82. Bulteau AL, Verbeke P, Petropoulos I, Chaffotte AF \& Friguet B (2001) Proteasome inhibition in glyoxal-treated fibroblasts and resistance of glycated glucose-6-phosphate dehydrogenase to $20 \mathrm{~S}$ proteasome degradation in vitro. J Biol Chem 276, 45662-45668.

83. Carrard G, Dieu M, Raes M, Toussaint O \& Friguet B (2003) Impact of ageing on proteasome structure and function in human lymphocytes. Int J Biochem Cell Biol 35, 728-739.

84. Stolzing A, Widmer R, Jung T, Voss P \& Grune T (2006) Degradation of glycated bovine serum albumin in microglial cells. Free Radic Biol Med 40, 1017-1027.

85. Stam F, Schalkwijk CG, van Guldener C, ter Wee PM \& Stehouwer CD (2006) Advanced glycation end-product peptides are associated with impaired renal function, but not with biochemical markers of endothelial dysfunction and inflammation, in non-diabetic individuals. Nephrol Dial Transplant 21, 677-682.

86. Gugliucci A \& Bendayan M (1996) Renal fate of circulating advanced glycated end products (AGE): evidence for reabsorption and catabolism of AGE-peptides by renal proximal tubular cells. Diabetologia 39, 149-160.

87. Agalou S, Ahmed N, Babaei-Jadidi R, Dawnay A \& Thornalley PJ (2005) Profound mishandling of protein glycation degradation products in uremia and dialysis. $J \mathrm{Am}$ Soc Nephrol 16, 1471-1485.

88. Odetti P, Cosso L, Pronzato MA, Dapino D \& Gurreri G (1995) Plasma advanced glycosylation end-products in maintenance haemodialysis patients. Nephrol Dial Transplant 10, 2110-2113.

89. Friedlander MA, Wu YC, Schulak JA, Monnier VM \& Hricik DE (1995) Influence of dialysis modality on plasma and tissue concentrations of pentosidine in patients with end-stage renal disease. Am J Kidney Dis 25, 445-451.

90. Miyata T, Ueda Y, Yoshida A, Sugiyama S, Iida Y, Jadoul M \& Maeda K, Kurokawa K \& van Ypersele de Strihou C (1997) Clearance of pentosidine, an advanced glycation end product, by different modalities of renal replacement therapy. Kidney Int 51, 880-887.

91. Sebekova K, Podracka L, Blazicek P, Syrova D, Heidland A \& Schinzel R (2001) Plasma levels of advanced glycation end products in children with renal disease. Pediatr Nephrol 16, 1105-1112.

92. Miyata T, Ueda Y, Shinzato T, Iida Y, Tanaka S, Kurokawa K, van Ypersele de Strihou C \& Maeda K (1996) Accumulation of albumin-linked and free-form pentosidine in the circulation of uremic patients with end-stage renal failure: renal implications in the pathophysiology of pentosidine. $J$ Am Soc Nephrol 7, 1198-1206.

93. Miyata T, Fu MX, Kurokawa K, van Ypersele de Strihou C, Thorpe SR \& Baynes JW (1998) Autoxidation products of both carbohydrates and lipids are increased in uremic plasma: is there oxidative stress in uremia? Kidney Int $\mathbf{5 4}$, 1290-1295.

94. Kalousova M, Zima T, Tesar V, Stipek S \& Sulkova S (2004) Advanced glycation end products in clinical nephrology. Kidney Blood Press Res 27, 18-28.

95. Miyata T, van Ypersele de Strihou C, Kurokawa K \& Baynes JW (1999) Alterations in nonenzymatic biochemistry in uremia: origin and significance of 'carbonyl stress' in long-term uremic complications. Kidney Int 55, 389-399.

96. Smedsrod B, Melkko J, Araki N, Sano H \& Horiuchi S (1997) Advanced glycation end products are eliminated by scavenger-receptor-mediated endocytosis in hepatic sinusoidal Kupffer and endothelial cells. Biochem J 322, 567573.

97. Hansen B, Svistounov D, Olsen R, Nagai R, Horiuchi S \& Smedsrod B (2002) Advanced glycation end products impair the scavenger function of rat hepatic sinusoidal endothelial cells. Diabetologia 45, 1379-1388.

98. Sebekova K, Kupcova V, Schinzel R \& Heidland A (2002) Markedly elevated levels of plasma advanced glycation end products in patients with liver cirrhosis - amelioration by liver transplantation. J Hepatol 36, 66-71.

99. Ahmed N, Thornalley PJ, Luthen R, Haussinger D, Sebekova K, Schinzel R, Voelker W \& Heidland A (2004) Processing of protein glycation, oxidation and nitrosation adducts in the liver and the effect of cirrhosis. J Hepatol 41, 913-919.

100. Forbes JM, Fukami K \& Cooper ME (2007) Diabetic nephropathy: where hemodynamics meets metabolism. Exp Clin Endocrinol Diabetes 115, 69-84.

101. Gurley SB \& Coffman TM (2007) The renin-angiotensin system and diabetic nephropathy. Semin Nephrol 27, 144152.

102. Rossing P, Parving HH \& de Zeeuw D (2006) Renoprotection by blocking the RAAS in diabetic nephropathy - fact or fiction? Nephrol Dial Transplant 21, 2354-2357.

103. Jacobsen PK (2005) Preventing end-stage renal disease in diabetic patients - dual blockade of the renin-angiotensin system (Part II). J Renin Angiotensin Aldosterone Syst $\mathbf{6}$, 55-68.

104. Thomas MC, Forbes JM \& Cooper ME (2005) Advanced glycation end products and diabetic nephropathy. Am J Ther 12, 562-572.

105. Tanji N, Markowitz GS, Fu C, Kislinger T, Taguchi A, Pischetsrieder M, Stern D, Schmidt AM \& D‘Agati VD (2000) Expression of advanced glycation end products and their cellular receptor RAGE in diabetic nephropathy and nondiabetic renal disease. J Am Soc Nephrol 11, 16561666.

106. Oldfield MD, Bach LA, Forbes JM, Nikolic-Paterson D, McRobert A, Thallas V, Atkins RC, Osicka T, Jerums G \& Cooper ME (2001) Advanced glycation end products cause epithelial-myofibroblast transdifferentiation via the receptor for advanced glycation end products (RAGE). J Clin Invest 108, 1853-1863.

107. Wendt TM, Tanji N, Guo J et al. (2003) RAGE drives the development of glomerulosclerosis and implicates podocyte activation in the pathogenesis of diabetic nephropathy. Am J Pathol 162, 1123-1137.

108. Bonnardel-Phu E, Wautier JL, Schmidt AM, Avila C \& Vicaut E (1999) Acute modulation of albumin microvascular leakage by advanced glycation end products in microcirculation of diabetic rats in vivo. Diabetes 48, 20522058.

109. Yamamoto Y, Kato I, Doi T et al. (2001) Development and prevention of advanced diabetic nephropathy in RAGEoverexpressing mice. J Clin Invest 108, 261-268.

110. Morcos M, Sayed AA, Bierhaus A et al. (2002) Activation of tubular epithelial cells in diabetic nephropathy. Diabetes 51, 3532-3544.

111. Babaei-Jadidi R, Karachalias N, Ahmed N, Battah S \& Thornalley PJ (2003) Prevention of incipient diabetic nephropathy by high-dose thiamine and benfotiamine. Diabetes 52, 2110-2120.

112. Degenhardt TP, Alderson NL, Arrington DD, Beattie RJ, Basgen JM, Steffes MW, Thorpe SR \& Baynes JW (2002) Pyridoxamine inhibits early renal disease and dyslipidemia in the streptozotocin-diabetic rat. Kidney Int 61, 939-950. 
113. Forbes JM, Thallas V, Thomas MC, Founds HW, Burns WC, Jerums G \& Cooper ME (2003) The breakdown of preexisting advanced glycation end products is associated with reduced renal fibrosis in experimental diabetes. FASEB $J$ 17, 1762-1764.

114. Thallas-Bonke V, Lindschau C, Rizkalla B, Bach LA, Boner G, Meier M, Haller H, Cooper ME \& Forbes JM (2004) Attenuation of extracellular matrix accumulation in diabetic nephropathy by the advanced glycation end product cross-link breaker ALT-711 via a protein kinase C-alpha-dependent pathway. Diabetes 53, 2921-2930.

115. Flyvbjerg A, Denner L, Schrijvers BF, Tilton RG, Mogensen TH, Paludan SR \& Rasch R (2004) Long-term renal effects of a neutralizing RAGE antibody in obese type 2 diabetic mice. Diabetes 53, 166-172.

116. Maillard L (1912) Action des acides aminés sur les sucres: formation des mélanoidines par voie méthodique (Action of amino acids on sugars: pathway of formation of melanoidins). C R Acad Sci 154, 66-68.

117. Somoza V (2005) Five years of research on health risks and benefits of Maillard reaction products: an update. Mol Nutr Food Res 49, 663-672.

118. Ahmed N, Mirshekar-Syahkal B, Kennish L, Karachalias N, Babaei-Jadidi R \& Thornalley PJ (2005) Assay of advanced glycation endproducts in selected beverages and food by liquid chromatography with tandem mass spectrometric detection. Mol Nutr Food Res 49, 691-699.

119. Goldberg T, Cai W, Peppa M, Dardaine V, Baliga BS, Uribarri J \& Vlassara H (2004) Advanced glycoxidation end products in commonly consumed foods. J Am Diet Assoc 104, 1287-1291.

120. Henle T (2005) Protein-bound advanced glycation endproducts (AGEs) as bioactive amino acid derivatives in foods. Amino Acids 29, 313-322.

121. Koschinsky T, He CJ, Mitsuhashi T, Bucala R, Liu C, Buenting C, Heitmann K \& Vlassara H (1997) Orally absorbed reactive glycation products (glycotoxins): an environmental risk factor in diabetic nephropathy. Proc Natl Acad Sci USA 94, 6474-6479.

122. Faist V \& Erbersdobler HF (2001) Metabolic transit and in vivo effects of melanoidins and precursor compounds deriving from the Maillard reaction. Ann Nutr Metab 45, 1-12.

123. Faist V, Wenzel E, Randel G et al. (2000) In vitro and in vivo studies on the metabolic transit of $\mathrm{N}$ carboxymethyllysine. Czech J Food Sci 18, 116-119.

124. Foerster A \& Henle T (2003) Glycation in food and metabolic transit of dietary AGEs (advanced glycation endproducts): studies on the urinary excretion of pyrraline. Biochem Soc Trans 31, 1383-1385.

125. Forster A, Kuhne Y \& Henle T (2005) Studies on absorption and elimination of dietary maillard reaction products. Ann NY Acad Sci 1043, 474-481.

126. Bergmann R, Helling R, Heichert C, Scheunemann M, Mading P, Wittrisch H, Johannsen B \& Henle T (2001) Radio fluorination and positron emission tomography (PET) as a new approach to study the in vivo distribution and elimination of the advanced glycation endproducts $\mathrm{N}$ epsilon-carboxymethyllysine (CML) and $\mathrm{N}$ epsiloncarboxyethyllysine (CEL). Nahrung 45, 182-188.

127. Wiame E, Delpierre G, Collard F \& Van Schaftingen E (2002) Identification of a pathway for the utilization of the Amadori product fructoselysine in Escherichia coli. J Biol Chem 277, 42523-42529.

128. Tuohy KM, Hinton DJ, Davies SJ, Crabbe MJ, Gibson GR \& Ames JM (2006) Metabolism of Maillard reaction products by the human gut microbiota - implications for health. Mol Nutr Food Res 50, 847-857.
129. Sebekova K, Hofmann T, Boor P, Sebekova K Jr, Ulicna O, Erbersdobler HF, Baynes JW, Thorpe SR, Heidland A \& Somoza V (2005) Renal effects of oral maillard reaction product load in the form of bread crusts in healthy and subtotally nephrectomized rats. Ann NY Acad Sci 1043, 482-491.

130. Sandu O, Song K, Cai W, Zheng F, Uribarri J \& Vlassara H (2005) Insulin resistance and type 2 diabetes in high-fat-fed mice are linked to high glycotoxin intake. Diabetes 54, 2314-2319.

131. Hofmann SM, Dong HJ, Li Z, Cai W, Altomonte J, Thung SN, Feng Z, Fisher E \& Vlassara H (2002) Improved insulin sensitivity is associated with restricted intake of dietary glycoxidation products in the $\mathrm{db} / \mathrm{db}$ mouse. Diabetes 51, 2082-2089.

132. Zheng F, He C, Cai W, Hattori M, Steffes M \& Vlassara H (2002) Prevention of diabetic nephropathy in mice by a diet low in glycoxidation products. Diabetes Metab Res Rev 18, 224-237.

133. Peppa M, He C, Hattori M, McEvoy R, Zheng F \& Vlassara H (2003) Fetal or neonatal low-glycotoxin environment prevents autoimmune diabetes in NOD mice. Diabetes 52, 1441-1448.

134. Peppa M, Brem H, Ehrlich P, Zhang JG, Cai W, Li Z, Croitoru A, Thung S \& Vlassara H (2003) Adverse effects of dietary glycotoxins on wound healing in genetically diabetic mice. Diabetes 52, 2805-2813.

135. Lin RY, Reis ED, Dore AT, Lu M, Ghodsi N, Fallon JT, Fisher EA \& Vlassara H (2002) Lowering of dietary advanced glycation endproducts (AGE) reduces neointimal formation after arterial injury in genetically hypercholesterolemic mice. Atherosclerosis 163, 303-311.

136. Lin RY, Choudhury RP, Cai W, Lu M, Fallon JT, Fisher EA \& Vlassara H (2003) Dietary glycotoxins promote diabetic atherosclerosis in apolipoprotein E-deficient mice. Atherosclerosis 168, 213-220.

137. Peppa M, Brem H, Cai W, Zhang JG, Basgen J, Li Z, Vlassara H \& Uribarri J (2006) Prevention and reversal of diabetic nephropathy in $\mathrm{db} / \mathrm{db}$ mice treated with alagebrium (ALT-711). Am J Nephrol 26, 430-436.

138. Zimanyi MA, Denton KM, Forbes JM, Thallas-Bonke V, Thomas MC, Poon F \& Black MJ (2006) A developmental nephron deficit in rats is associated with increased susceptibility to a secondary renal injury due to advanced glycation end-products. Diabetologia 49, 801-810.

139. Uribarri J, Cai W, Sandu O, Peppa M, Goldberg T \& Vlassara H (2005) Diet-derived advanced glycation end products are major contributors to the body's AGE pool and induce inflammation in healthy subjects. Ann NY Acad Sci 1043, 461-466.

140. Uribarri J, Cai W, Peppa M, Goodman S, Ferrucci L, Striker G \& Vlassara H (2007) Circulating glycotoxins and dietary advanced glycation endproducts: two links to inflammatory response, oxidative stress, and aging. J Gerontol A Biol Sci Med Sci 62, 427-433.

141. Vlassara H, Cai W, Crandall J, Goldberg T, Oberstein R, Dardaine V, Peppa M \& Rayfield EJ (2002) Inflammatory mediators are induced by dietary glycotoxins, a major risk factor for diabetic angiopathy. Proc Natl Acad Sci USA 99, 15596-15601.

142. Cai W, He JC, Zhu L, Peppa M, Lu C, Uribarri J \& Vlassara H (2004) High levels of dietary advanced glycation end products transform low-density lipoprotein into a potent redox-sensitive mitogen-activated protein kinase stimulant in diabetic patients. Circulation 110, 285-291.

143. Negrean M, Stirban A, Stratmann B et al. (2007) Effects of low- and high-advanced glycation endproduct meals on 
macro- and microvascular endothelial function and oxidative stress in patients with type 2 diabetes mellitus. Am J Clin Nutr 85, 1236-1243.

144. Uribarri J, Stirban A, Sander D, Cai W, Negrean M, Buenting CE, Koschinsky T \& Vlassara H (2007) Single oral challenge by advanced glycation end products acutely impairs endothelial function in diabetic and nondiabetic subjects. Diabetes Care 30, 2579-2582.

145. Peppa M, Uribarri J, Cai W, Lu M \& Vlassara H (2004) Glycoxidation and inflammation in renal failure patients. Am J Kidney Dis 43, 690-695.

146. Schwedler SB, Metzger T, Schinzel R \& Wanner C (2002) Advanced glycation end products and mortality in hemodialysis patients. Kidney Int 62, 301-310.

147. Lieuw AFML, van Hinsbergh VW, Teerlink T, Barto R, Twisk J, Stehouwer CD \& Schalkwijk CG (2004) Increased levels of N(epsilon)-(carboxymethyl)lysine and $\mathrm{N}$ (epsilon)-(carboxyethyl)lysine in type 1 diabetic patients with impaired renal function: correlation with markers of endothelial dysfunction. Nephrol Dial Transplant 19, 631-636.

148. Busch M, Franke S, Wolf G, Brandstadt A, Ott U, Gerth J, Hunsicker LG, Stein G \& Collaborative Study Group (2006) The advanced glycation end product N(epsilon)carboxymethyllysine is not a predictor of cardiovascular events and renal outcomes in patients with type 2 diabetic kidney disease and hypertension. Am J Kidney Dis 48, 571579.

149. Sebekova K, Krajcoviova-Kudlackova M, Schinzel R, Faist V, Klvanova J \& Heidland A (2001) Plasma levels of advanced glycation end products in healthy, long-term vegetarians and subjects on a western mixed diet. Eur $J$ Nutr 40, 275-281.

150. Sebekova K, Boor P, Valachovicova M, Blazicek P, Parrak V, Babinska K, Heidland A \& Krajcovicova-Kudlackova M (2006) Association of metabolic syndrome risk factors with selected markers of oxidative status and microinflammation in healthy omnivores and vegetarians. Mol Nutr Food Res 50, 858-868.

151. Ordovas JM \& Mooser V (2004) Nutrigenomics and nutrigenetics. Curr Opin Lipidol 15, 101-108.

152. Cai W, Gao QD, Zhu L, Peppa M, He C \& Vlassara H (2002) Oxidative stress-inducing carbonyl compounds from common foods: novel mediators of cellular dysfunction. Mol Med 8, 337-346.

153. Zill H, Bek S, Hofmann T et al. (2003) RAGE-mediated MAPK activation by food-derived AGE and non-AGE products. Biochem Biophys Res Commun 300, 311-315.

154. Leslie RD, Beyan H, Sawtell P, Boehm BO, Spector TD \& Snieder H (2003) Level of an advanced glycated end product is genetically determined: a study of normal twins. Diabetes 52, 2441-2444.

155. Kankova K, Stejskalova A, Pacal L et al. (2007) Genetic risk factors for diabetic nephropathy on chromosomes $6 \mathrm{p}$ and $7 \mathrm{q}$ identified by the set-association approach. Diabetologia 50, 990-999.

156. Delpierre G, Veiga-da-Cunha M, Vertommen D, Buysschaert M \& Van Schaftingen E (2006) Variability in erythrocyte fructosamine 3-kinase activity in humans correlates with polymorphisms in the FN3K gene and impacts on haemoglobin glycation at specific sites. Diabetes Metab 32, 31-39.

157. Kankova K, Zahejsky J, Marova I, Muzik J, Kuhrova V, Blazkova M, Znojil V, Beranek M \& Vacha J (2001) Polymorphisms in the RAGE gene influence susceptibility to diabetes-associated microvascular dermatoses in NIDDM. J Diabetes Complications 15, 185-192.

158. Kankova K, Marova I, Zahejsky J, Muzik J, Stejskalova A, Znojil V \& Vacha J (2001) Polymorphisms 1704G/T and $2184 \mathrm{~A} / \mathrm{G}$ in the RAGE gene are associated with antioxidant status. Metabolism 50, 1152-1160.

159. Kankova K, Stejskalova A, Hertlova M \& Znojil V (2005) Haplotype analysis of the RAGE gene: identification of a haplotype marker for diabetic nephropathy in type 2 diabetes mellitus. Nephrol Dial Transpl 20, 1093-1102.

160. Pettersson-Fernholm K, Forsblom C, Hudson BI, Perola M, Grant PJ \& Groop PH (2003) The functional-374 T/A RAGE gene polymorphism is associated with proteinuria and cardiovascular disease in type 1 diabetic patients. Diabetes 52, 891-894.

161. Matsunaga-Irie S, Maruyama T, Yamamoto Y, Motohashi Y, Hirose H, Shimada A, Murata M \& Saruta T (2004) Relation between development of nephropathy and the p22phox C242T and receptor for advanced glycation end product G1704T gene polymorphisms in type 2 diabetic patients. Diabetes Care 27, 303-307. 